\title{
Soul or Brain: A False Dilemma? The Thomist Perspective
}

\section{JÖRGEN VIJGEN}

Thomas Instituut te Utrecht (Netherlands)

jorgen.vijgen@skynet.be

\begin{abstract}
In this article I will claim that from a Thomist perspective the question "Soul or Brain: What makes us human?" presents us with a false dilemma and hence must as such remain an unanswerable question. In order to corroborate this claim I will do two things. First, I present the framework of a Thomistic anthropology in so far as it relates to the unity of soul and body in the human person. Next, I deal with the question that immediately results from this unity, i.e. the subsistence of the soul. From a Thomist perspective this question can be answered apart from any findings from neuroscience.
\end{abstract}

Keywords: Thomas Aquinas; anthropology; soul; body.

\section{Introduction}

If we take the question "Soul or Brain: What makes us human?" ${ }^{1}$ at face value, we are presented with a dilemma which forces us to take a position in which either the soul or the brain is that which defines our human nature.

1 This contribution has as its origin an intervention during an interdisciplinary workshop entitled "Soul or Brain: What makes us human?" at the Nicolaus Copernicus University in Torun, Poland on 19-21 October 2016. Both the intervention as well as this contribution intends to offer a Thomistic framework to the debate. For a much more detailed account of Aquinas' position in dialogue with the different currents within the philosophy of mind I refer for instance to Kläden (2005). 
In this article I will argue that the formulation of the question from a Thomist perspective presents us with a false dilemma because the question already contains in itself the presumed answer and implicitly reveals a dualistic mindset. From a Thomist perspective, however, any identification of the human being with either the soul or the brain runs counter to the unity of soul and body in the human being. After briefly outlining the historical background of Aquinas' position, I will explore in part 1 the body-soul unity more in depth from the perspective of the body (brain) and of the soul. In part 2, I will address the question that immediately results from the body-soul unity, i.e. the subsistence of the human soul. This question, I will argue, can be answered within a Thomist perspective apart from any findings in neuroscience.

One of the distinguishing features of the Thomist tradition, both historically and systematically, is the defense of the unity of soul and body in man (Elders 1997), a defense which is directed against the identification of man with his soul. For Thomas Aquinas this defense was necessary in light of the Platonic tradition of some Church Fathers, and in particular the early Augustine (Augustine 1986, 158; 1955, 776), for whom the soul was considered to be a complete substance which made use of the body as an instrument at best or was burdened by the body at worst (Bochet 2016).

The rediscovery of Aristotle's writings and in particular the introduction of the De anima in the Latin West (De Boer 2013) at first did not contribute to overcoming this Platonic dualism. For Aquinas's immediate predecessors and contemporaries, soul and body remain in some way two substances (Wéber 1991; Hasse 2000, 80-91; Bieniak 2013, 9-46; Blankenhorn 2015, 215-248). Even Aquinas's own teacher, Albert the Great, defends an eclectic position (Bazan 1997), distinguishing between two different (Platonic vs Aristotelian) spheres of inquiry. He writes: "If we consider the soul in itself (secundum se), then we agree with Plato; but if we consider it according to the form which it gives to the body and animates it, then we agree with Aristotle.” (Albertus 1895, 16b)

If one were to say that the individual man is identical to his soul then this would have far reaching consequences regarding the question 'which 
is the subject to whom the actions of this individual man should be attributed'. For if the individual man is identical to his soul, only the soul can be regarded as being the true subject of that man's actions. This radically Platonic position would entail that even the acts of sensation have as their subject the soul, a view which Thomas rejects as contrary to common sense experience, by which we realize that it is the soul body unity which performs acts of sensation (ST I, 74, 4c).

This radically Platonic position would also entail that the subject of the intellectual acts of an individual man is radically different from the subject of the acts of sensation. Again, Thomas views this position, which holds that an individual man contains within himself two radically different subjects, as contrary to common sense experience for it would follow that an individual man "is not one absolutely, and consequently neither a being absolutely, for a thing is a being according as it is one" (ST I, 76, 1c).

Given this common sense experience, Thomas is able to adopt a hylomorphic account of the body-soul unity. In such an account the form of a thing is that whereby the thing primarily acts (ST I, 76, 1c) and the form of man is that whereby a man acts in a specifically human manner, i.e. through intellectual knowledge. Hence, the intellectual soul must be the form of the body.

The other extreme would be to say that an individual man is identical to the body, understood as a mere collection of mechanically operating parts. The reason why Thomas has devoted no attention to this other extreme is fairly apparent. This - merely speculative - position would implicitly equate the human body with formless matter, which is mere potency and of which it is impossible to predicate existence properly. Matter, therefore, cannot have an entitative act but receives this act from the matter-form unity of a substance. A living human body therefore is always informed by the soul and the human body cannot exist in its own right apart from the soul. It is therefore telling that the expression "I am my body", as formulated by Merleau-Ponty in his Phenomenology of Perception $(2002,296)$ and by Gabriel Marcel in his The Mystery of Being $(2001,100)$ is sharply directed against Cartesian dualism. 
With this brief outline in place, I will in part 1 analyze the consequences of this body-soul unity from the perspectives of the brain, which one can regard as a totum pro parte of the body, and from the perspective of the soul. In using the term 'perspective', I want to emphasize that within the integrated Thomistic account of the human being, body and soul are distinct and real but not as an unqualified this, they "are not two kinds of thing needing to be unified by yet a third kind" (Brock 2015, 48-49) but rather perspectives on the whole of the substantial unity.

\section{The soul body unity}

\subsection{From the perspective of the body (brain)}

From his earliest writings onward, Thomas defended the twofold claim that first, sensory images are the source from which the content of intellectual knowledge is abstracted and second, that these sensory images are that to which the intellect must turn back in order to actually know something (conversio ad phantasmata) (In II Sent., 20, 2, 2, ad 3; ScG II, 73; ST I, 87, 8). Consequently, every intellectual act involves to some extent the bodily organism and its organs or - more particularly - the brain and as such every intellectual act is somehow measurable.

Thomas recognizes very clearly that not only the external senses but also the internal senses have as a necessary condition the properly functioning activities of the body and in particular the brain. The internal senses, i.e. the common sense (ST I, 78, 4, ad 2; In De Anima III, 1. 3, nrs. 599-600), imagination (ST I, 78, 4; In De Anima III, lect. 6, nrs. 664-665), sensitive memory (ST I, 78, 4) and estimative sense (cogitative sense in humans) (ST I, 78, 4; In De Anima III, lect 6, nr. 398) are not those senses which are in contact with the things they perceive as is the case with the external senses, but are those senses which account for the preservation of what has been perceived and the recognition and provision of instinctive knowledge.

The involvement of the bodily organism and the brain in the acquisition of knowledge can be illustrated by the following four examples. Firstly, 
the necessary dependence of the internal senses mentioned above on the brain as its organ according to Thomas is illustrated by the following texts. Thomas writes, "man, in proportion to his size, has a larger brain than any other animal, because a good disposition of the brain is necessary for the good condition of the internal sentient powers, namely, the imagination, the memory, and the cogitative power." (Q.D. De Anima, q. un., a. 8 c). Elsewhere, he writes as follows: "man needs the largest brain as compared to the body for his greater freedom of action in the interior powers required for the intellectual operations" (ST I, 91, 3, ad 1).

Secondly, and influenced by Aristotle (Nicomachean Ethics VII, 6, 1149a24), Thomas equally recognizes the influence of what he calls "natural temperament" (complexio naturalis) on the formation of virtues and vices, for instance when, in distinguishing between a "bodily" and a "spiritual" cause of concupiscence he writes: "some people by their natural temperament are more prone to concupiscence than others” (ST II-II, 155, 4, ad 2). One could identify this natural temperament with what today is called neurological or genetic predispositions which can vary from person to person. These bodily causes remain merely occasional causes rather than direct causes because Aquinas is convinced that man, "as long as the use of reason remains" (ST II-II, 4; also In II Sent., d. 25, 1, 1, ad 5), can resist these bodily causes.

Thirdly, he also recognizes that the intellect, because its proper and proportionate object is the nature of a sensible thing, can be hindered by suspension of the external and internal senses (ST I, 84, 8). This occurs for instance in the case of persons in a frenzy or in a lethargic state in which cases the acts of imagination (frenzy) and memory (lethargy) are hindered (ST I, 87, 4; ScG III, 84). But not even self-knowledge is merely an act of the intellect because, as Thomas says, "if certain corporeal organs have been harmed, the soul cannot directly understand either itself or anything else, as when the brain is injured." (De Spir. Creat., q. un., 2, ad 7).

Fourthly and finally, Thomas is also aware, despite his outdated explanations, of the interdependency of soul and body in causing certain psychosomatic illnesses (aegritutodo animalis) such as various anxiety disorders (In VII Ethic., 1. 5, n. 1380), eating disorders (In III Ethic., 1. 20, n. 623; 
ST II-II, 148, 6, ad 2) and sexual and other perversions such as sadism, etc. (ST II-II, 157, 1 ad 3). In fact, Thomas would oppose the notion of 'mental illness' because the mind as such cannot be ill but merely err (intellect) or be evil (will). A so-called 'mental' illness has a bodily cause which subsequently can manifest itself in a pathological form of the intellect's or the will's acts (In I De Anima, 1. 10, nrs. 163-164).

Much more could be said about these and other examples (Echavarría 2009, 375-562) but what they show is that for Thomas the body and the brain (taken as totum pro parte) act as a material, dispositive and instrumental cause, i.e. the body and the brain offer as an instrumental agent cause the material and the disposition for the production of the ultimate effect by another agent cause, the intellect. This type of causality should not be misunderstood: any parallelism or even conditional relation between soul and body (brain) does not in itself constitute an argument for emergence Moreover, this purely observable type of causality has its intrinsic limits due to the methodology employed by modern science. Modern science is by definition operative on the level of what is quantitatively measurable and as such studies merely the quantitative aspect of things whereas the Aristotelian-Thomistic philosophy of nature "is concerned with the entire reality" (Elders 1997, 26). As Robert Augros observed: "A scientist has neither any reason nor any need to deny that there might be ways of understanding nature besides the way of measurement." (Augros 2004, 131).

The differentiated unity of soul and body defended by Aquinas implies the view that the body contributes in a positive manner to the soul and its operations. Aquinas views this contribution of the body as crucial to such an extent that he can affirm that the intellectual soul is united to the body for the sake of the soul. In so far as the body is necessary for the intellectual soul and in so far as the unity of soul and body exists for the sake of the soul, the body is always 'charged' with meaning and never exists as a "morally neutral playground" (Gondreau 2008, 749). As such there exists for Thomas a qualitative difference between the human body (united to an intellectual soul) and the body of an animal, a difference which Thomas expresses as follows: "the body is a certain fullness of the soul (quadam plenitudo animae)" 
(In Ephesians 1:23, nr. 71). Marie-Joseph Nicolas comments by writing that the human body is "le champ expressif de l'âme" or "la face extérieure de lame" (Nicholas 1979, quoted in Emery 2000, 225).

\subsection{From the perspective of the soul}

Aquinas's position that the soul is the one and only substantial form of the body is at odds with a Cartesian view of the soul as an immaterial part of the human being. Aquinas's position entails that, although the soul is not identical with the body, the soul belongs to the nature of a bodily substance. It does so because the soul is the principle of the unity of the body and as such the soul constitutes the body. In other words, the soul does not have a species of its own, otherwise it would be an angel (ST I, 90,4 , ad 2); it is not a complete, fully distinct entity but part of a complete entity, a human being. Aquinas, moreover, qualifies our way of speaking regarding the human being in terms of parts or components. Following Aristotle, he distinguishes between a logical and a metaphysical approach (In Meta. VII, 1. 13, nr. 1576). The elements of a definition do not necessarily correspond to components or parts of the thing defined by the definition. Hence, our way of speaking in terms of parts or components does not entail that a human being consists of two previously separated parts, now joined together. Rather, his position on the unity of the substantial form entails that the form, i.e. the soul, is constitutive of something that is both rational and bodily. Stephen Brock expresses Aquinas's position as follows: "Man's formal principle is something spiritual; but it is nevertheless a principle of something physical and essentially so. Its nature is proportioned to that of which it is the principle. Even if it is "on the border" [referring to ST I, 77, 2] of spiritual and bodily creatures, its natural home is clearly in the physical world.” (Brock 2005, 234).

In this view, the soul by itself is not a complete subject, it does not exhaust the totality of what it means to be a human person. Hence, the soul cannot be viewed as identical to the modern Cartesian-like 'self', which would somehow and somewhere be present in the body. As the unique substantial 
form of the body, the soul is everywhere and nowhere. Not only is the soul not part of the body, metaphysically speaking, but neither is the soul a part of the body, locatable as it were in some place. Concretely this view entails that the human being, as a rational animal, is not characterized by 'pure thinking' but by 'sensing thinking'. In the words of Aquinas: "it is the very man himself who perceives himself both to understand and to sense; but sensing is not without the body, and so the body must be some part of the man” (ST I, 76, a).

I therefore think that the debate between survivalists and corruptionists largely rests on a truncated account of the soul-body unity, as understood by Aquinas. By means of his account, Aquinas is able to affirm both, i.e. the human being continues to exist in some way (survivalism), but the human being, for whom the body is integral to his nature, also ceases to exist after death (corruptionism). In other words, the state of existence of the separated soul is both a state of existence as well as a state of severely diminished existence. Because of the separation of body and soul from the body-soul unity of substance, the separated soul is no longer an individual substance and hence it is no longer possible to apply a definition or a name to such a separated soul (ST I, 29, 1, ad 5). The fact that a separated soul is no longer an individual substance does not, however, entail the disappearance of the soul of the human being, to which it belonged before death; rather it subsists as soul of that human being. Put briefly, John continues to exist after death as the soul of John (survivalism) but not as John (corruptionism) but in a state, deprived of "the perfection of its [the soul's] nature" (ST I, $118,3)$. Thomas is entirely consistent when, regarding a theological matter that was widely disputed in his time (Wéber 1991), he holds on to the view that Christ was no longer a man during the days of the Triduum of his death. For if Christ were still a man during the days of the Triduum of his death, that would for him entail the heretical ("contra fidem" ST III, 50, 4) view that Christ was not truly dead and hence that mankind would not be truly saved. The fact that Aquinas holds on to his largely Aristotelian anthropology is a testimony to his guiding principle that grace does not destroy, but perfects nature. 


\section{The role of the arguments for the subsistence of the human soul}

If actuality is constitutive of the form and if the soul is the form of the body, no matter, being anything merely potential, can enter in the composition of the soul itself (ST I, 75, 5). However, if the soul-body unity is as tight as described in part 1, it seems that both cannot exist without each other. In fact, Thomas admits as much when he writes: "It is also clear from what was said in Book II that the soul is naturally united to the body, for in its essence it is the form of the body. It, then, is contrary to the nature of the soul to be without the body" (ScG IV, 79). The soul-body unity requires therefore an investigation into the possibility of the subsistence of the soul after death, i.e. the fact that the soul possesses in itself something by which it remains in being. From a Thomist perspective this question can be answered apart from any findings from neuroscience. In what follows I will present three arguments in favor of the subsistence of the human soul which can be found explicitly or implicitly in Aquinas' writings and provide analogies which illustrate his reasoning. ${ }^{2}$

The argument from the uniqueness of intellectual knowledge is Aquinas's preferred argument. Sensorial knowledge always requires a material organ. These sensorial processes (for instance from the eyes, along the optic nerve, to the brain) are well documented and can be described by neuroscience. The objects of these sensorial processes are always concrete, particular objects. The object of intellectual knowledge, however, is not an individual object but an abstract object, that is, something which is the result of abstraction and it is grasped by the intellect according to the ratio of what is common to all particular objects. On the basis of this difference between absolute and particular objects, one can construct the following argument for the immateriality of the intellect. Every material organ grasps a particular whereas the intellect grasps the abstract or universal. The abstract or the universal are therefore not grasped by a material organ. The intellect's activity therefore, although made possible by bodily organs, does not consist in the activity of a bodily,

2 For the textual evidence, see ST I, 75, 5; De Ver. 10, 8; ScG II, 79 and Oguejiofor (2001). 
material organ. For Thomas, a denial of the immateriality of the intellect would make an answer to the following question impossible: How could something that is not individual be grasped by something that is individual, given that a material organ is by nature limited and limiting, able to facilitate knowledge only of certain things or of certain aspects of a thing (the eye sees color, touch manifests the texture of a body, etc.)? The object of knowledge must be proportioned to the intellect. Only an intellect that is not material itself can grasp something non-material such as a universal. If intellectual activity proceeds through universal concepts and applies to being as such universally, a wholly physicalist account of intellectual knowledge becomes a contradictio in terminis because it reduces what is universal to what is material and hence particular. The following analogy can be useful. Following a reductionist account of intellectual knowledge, one would have to say that to every universal concept corresponds a match we place in a matchbox every time there occurs an intellectual activity. There could, however, never be enough matches in the matchbox if it is possible that there exist non-particular, universal concepts. In short, there is no proportion between a limited set of matches and the formulation of unlimited, universal concepts.

Moreover and more fundamentally, in a reductionist account the adaequatio of intellect to reality becomes impossible. The metaphysical principle that being is not non-being and its subsequent logical expression in the principle of non-contradiction provides the basis for objectivity. In a reductionist account the intellect's capacity to form universal concepts and hence the capacity to conform to a state of affairs is being reduced to or identified with a set of particulars such as brain functions. In such an account the adaequatio of intellect to reality becomes impossible because the intellect would only have contact with particular brain states and would not possess the capacity to judge these brain states as to their adequacy regarding anything beyond theses brain states. ${ }^{3}$

A second argument is the argument from self-reflection and self-experience. If one grants the existence of lived and inner acts of self-reflection

3 Hence the principle that "intellectual knowledge is in inverse ratio of materiality" in ST I, 84,2 . 
and self-experience and if one grants the necessity of the presence of a conscious and indivisible subject from which these inner acts proceed, then a material and composite entity such as brain cannot be a sufficient condition for these inner acts. Thomas writes: "the action of no body is self-reflexive. For it is proved in the Physics that no body is moved by itself except with respect to a part, so that one part of it is the mover and the other the moved. But in acting the intellect reflects on itself, not only as to a part, but as to the whole of itself. Therefore, it is not a body" (ScG II, 49). The following analogy might be helpful. Suppose I am listening to a Mahler symphony. Both the external process of the activity of listening as well as its corresponding brain activities can be registered. Given that the process of listening cannot exist without temporarily and spatially extended parts and phases, it is evident that the process requires a material entity as bearer. The registration and corresponding description of the external process, however, does not account for the self-reflective experience of the subject who does the listening. In other words, the aesthetic reality of the experience by a self-reflective subject, although requiring a material bearer, is not exhausted by the external registration and description of the corresponding brain processes, and even more, the aesthetic reality cannot be realized by a subject who possesses the same material features as the musical score and its audible performance.

A third argument proceeds from the experience of free acts and argues that the experience and existence of such free acts is both unintelligible and metaphysically impossible if these acts are merely identical with or fully determined by material processes such as these of the brain. An excellent illustration of this argument, albeit in the form of a reduction ad absurdum, is offered by Hans Jonas in the following story (Jonas 1981, 13). The German scientist Hermann Ludwig Ferdinand von Helmholtz (1821-1894) and his friends vowed that they would only admit a strictly materialistic explanation of the human person. However, as Jonas remarks, an analysis of such a vow shows that such a vow only makes sense, that is, such a vow can only be meaningfully uttered on the assumption that the vow could and would be kept. Such an assumption, however, presupposes that the act of vowing is causally 
independent from brain processes, a presupposition which at the same time is being denied by their own reductionist materialism. In other words, in the very moment of making that vow von Helmholtz and his friends contradict their own theory of materialism. This story could be extended to every free act because by definition a free act does not proceed from any other cause than the human person ${ }^{4}$ and as such free acts cannot exist in a materialistic account. ${ }^{5}$

These and other arguments are the Thomistic basis for the conclusion that the human soul is a subsistent principle, sc. it executes its operation of knowing and willing by itself and therefore exists or subsists also by itself and hence has no principle of corruption within itself. An important remark is in order at this point. The subsistence of the soul is often viewed as a return of substantial dualism. Regarding the conditions for existing as an individual substance, Thomas, however, writes: "an individual in the genus of substance is capable not only of subsisting of itself, but is also a complete entity belonging to a definite species and genus of substance” (De Anima, q. un., a. 1 c). Gilles Emery has pointed out, therefore, that there are two ontological conditions that need to be met in order to have a fullfledged substance dualism. A substance "needs to subsist by itself" and "it needs to be complete in its own species, that is, to possess everything that is required by the nature of such a thing." The soul is a reality complete in itself, but it does not constitute the whole essence of man. Hence, while the soul does possess an "independence of existence" with regard to matter and thus fulfills the first condition, it does not fulfill the second condition because it does not possess an "independence of essence” (Emery 2007, 222).

\section{Conclusion}

The question in the introduction ("Soul or brain: what makes us human?”) is from a Thomist perspective an unanswerable question because the

4 At least at the level of horizontal causality and not taking into account the vertical causality (praemotio physica) of God.

5 For a more comprehensive textual basis in Aquinas of arguments 2 and 3 see Scarpelly Cory (2016). 
questions presents us with a situation without choice. Why is this? Soul or brain are not and cannot be for Aquinas separate alternatives. Neither the soul nor the body or the brain as part of the body is a complete, fully distinct entity but are metaphysical parts of a complete entity, a human being. Thomistic hylomorphism entails the idea that the actuality of the body (matter) is derivative of the soul (form), which is the principle of vital activity and substantial unity. The soul-body unity runs counter to the idea of a predetermined body and a predetermined soul, coming together to form a merely accidental union. In a Thomistic hylomorphism, on the contrary, one can easily admit, as Aquinas does, the real influence of the brain on the activities of the soul.

Presenting the soul or the brain as alternative defining characteristics of man, assumes an entirely different anthropology, a typically Cartesian anthropology which considers the body and the soul as two substances, each with its own essential attribute, consciousness and extension. In such an anthropology and given the advances in neuroscience there can occur the risk of looking for a 'soul of the gaps'. From a Thomistic perspective, however, the soul is not a neuroscientific concept but a metaphysical and anthropological reality which, as such, is able to subsist as our experiences of intellectual, personal and moral knowledge show.

Let me close these observations by offering a Catholic disclaimer. From the perspective of Catholic philosophy and theology, it is also crucial to recall what Hans Urs von Balthasar has called the 'form of thought' or Denkform of Catholic thought (Balthasar 1951), a notion coined in his discussion with Karl Barth and taken up extensively by Leo Scheffczyk. According to Leo Scheffczyk, a 'form of thought' is a formal principle which gives a structure to all the conceptual content (Scheffczyk 2008, 34-45). Such a form of thought is not so much a matter of logic, although it is certainly influenced by a specific view of the world, but is much more connected to one's experience and tradition through which reality enters into the mind. Now, the Catholic form of thought is, as Barth himself admits, always a "Theologie des 'und'" (Barth 1948, 619), a form of thought in which two seemingly contrary aspects are being kept together in a unity-in-distinctness, a complementary of the 
relation of, say, nature and grace, Scripture and Tradition, faith and merit, the individual and the community, theology and philosophy, such that it is erroneous to ignore both their distinction as well as their union (Royal 2016, 152-164). One could easily add to this list the unity-in-distinctness of soul and body (brain).

\section{Abbreviations}

For the works of Thomas Aquinas I have used the well-known abbreviations and divisions: ST (Summa Theologiae), ScG (Summa contra Gentiles), In Meta. (Sententia libri Metaphysicae), In Ethic. (Sententia libri Ethicorum), In Sent. (Scriptum super Sententiis), etc. All English translations are taken from: http://dhspriory.org/thomas.

\section{References}

Albertus Magnus. 1895. Summa theologiae, edited by Augustus Borgnet, t. 33. Paris: Vivès.

Anzulewicz, Henryk. 2013. "Anthropology: The Concept of Man in Albert the Great." In A Companion to Albert the Great, edited by Irvin M. Resnick, 325-346. Leiden / Boston: Brill.

Aquinas, Thomas. 2001. S. Thomae de Aquino Opera omnia, edited by Enrique Alarcón, Pampilonae: Ad Universitatis Studiorum Navarrensis. http://www. corpusthomisticum.org

Augustine, Aurelius. 1986. De quantitate animae, edited by Wolfgang Hörmann.

Vindobonae : Hoelder-Pichler-Tempsky (Corpus Scriptorum Ecclesiasticorum Latinorum 89).

Augustine, Aurelius. 1955. De Civitate Dei, edited by Bernhard Dombart. Turnhout: Brepols (Corpus Christianorum Series Latina 48).

Augros, Robert. 2004. "Reconciling Science with Natural Philosophy." The Thomist 68:105-141.

Balthasar, Hans Urs Von. 1951. Karl Barth. Darstellung und Deutung seiner Theologie, Köln: Hegner.

Barth, Karl. 1948. Kirchliche Dogmatik, Bd I/2, Zürich, EVZ.

Bazan, Bernardo C. 1997. "The Human Soul: Form and Substance? Thomas Aquinas' Critique of Eclectic Aristotelianism.” AHDLMA 64:95-126. 
Bieniak, Magdalena. 2010. The Soul-Body Problem at Paris ca 1200-1250: Hugh of St-Cher and His Contemporaries. Leuven University Press: Leuven.

Blankenhorn, Bernard. 2015. The Mystery of Union with God. Dionysian Mysticism in Albert the Great and Thomas Aquinas. CUA Press: Washington D.C.

Bochet, Isabelle. 2016. "Le corps: un poids pour l'âme. L'exégèse augustinienne de Sagesse 9, 15.” Revue des sciences philosophiques et théologiques 100:27-43.

Brock, Stephen L. 2005. “The Physical Status of the Spiritual Soul in Thomas Aquinas.” Nova et Vetera. (English Edition) 2:231-258.

De Boer, Sander. 2013. The Science of the Soul: The Commentary Tradition on Aristotle's De Anima, c. 1260 - c. 1360. Leuven University Press: Leuven.

Echavarría, Martín F. 2009. La praxis de la psicología y sus niveles epistemológicos según santo Tomás de Aquino. Editorial de la Universidad Católica de La Plata: La Plata.

Elders, Leo. 1997. The philosophy of nature of St. Thomas Aquinas. Peter Lang: Frankfurt am Main.

Emery, Gilles. 2000. L'unité de l'homme, âme et corps, chez S. Thomas d'Aquin. Nova et Vetera 75:53-76.

Emery, Gilles. 2007. Trinity, Church, and the Human Person. Thomistic Essays. Naples (FL): Sapientia Press.

Gondreau, Paul. 2008. "The inseparable connection between procreation and unitive love and Thomistic hylomorphic anthropology.” Nova \& Vetera. (English Edition) 4:731-764.

Hasse, Dag N. 2000. Avicenna's De Anima in the Latin West. Warburg Institute: London. Jonas, Hans. 1981. Macht oder Ohnmacht der Subjektivität? Das Leib-Seele-Problem im Vorfeld des Prinzips Verantwortung. Frankfurt am Main: Insel. (Das Prinzip Verantwortung. Erster Teilband: Grundlegung, edited by Dietrich Böhler and Bernadette Herrmann, 421-510. Freiburg im Breisgau: Rombach (Kritische Gesamtausgabe der Werke von Hans Jonas I,2a).

Kläden, Tobias. 2005. Mit Leib und Seele... Die mind-brain-Debatte in der Philosophie des Geistes und die anima-forma-corporis-Lehre des Thomas von Aquin. Regensburg: Friedrich Pustet Verlag.

Luyten, Norbert. 1963. “The significance of the body in a Thomistic anthropology.” Philosophy Today 7:175-193.

Marcel, Gabriel. 2001. The Mystery of Being. Translated by G. S. Fraser. South Bend IN: St. Augustine's Press. (Original French: Le Mystère de l'être. Paris: Aubier, 1951). Merleau-Ponty, Maurice. 2002. The Phenomenology of Perception. Translated by C. Smith. Routledge: London and New York. (Original French : Phénoménologie de la Perception. Gallimart: Paris, 1945).

Nicolas, Marie-Joseph. 1979. “Le corps humain,” Revue Thomiste 79:357-387. 
Oguejiofor, Josephat O. 2001. The Philosophical Significance of Immortality in Thomas Aquinas. The University Press of America: New York.

Royal, Robert. A Deeper Vision: The Catholic Intellectual Tradition in the Twentieth Century. San Francisco: Ignatius Press.

Scarpelly Cory, Therese. 2016. "The Reflexivity of Incorporeal Acts as Source of Freedom and Subjectivity in Aquinas." In Subjectivity and Selfhood in Medieval and Early Modern Philosophy, edited by Jari Kaukua and Tomas Ekenberg, 125-141. Dordrecht: Springer.

Scheffczyk, Leo. 2008. Katholische Glaubenswelt. Wahrheit und Gestalt. Paderborn: Schoeningh, 3. durchgesehene Auflage, Original edition 1977.

Wéber, Edouard H. 1991. La personne humaine au XIIIe siècle. Vrin: Paris.

Weisheipl, James A. 1980. Thomas d'Aquino and Albert, his Teacher. PIMS: Toronto. 